\author{
Herna Sianturi \\ Universitas Prima Indonesia \\ Christina Siahaan \\ Universitas Prima Indonesia \\ Syarifah Isma Dinda \\ Universitas Prima Indonesia \\ Yenita Br Sembiring \\ Universitas Prima Indonesia \\ hernasianturi06@gmail.com
}

Submit, 15-01-2020 Accepted, 30-01-2020 Publish, 06-02-2020

\begin{abstract}
This research aims to find out the student's Reading Descriptive Text. The method used in this research is qualitative; the study was conducted at SMA Swasta Pencawan Medan with the samples were 30 students of XI MIA-2. The researcher used multiple-choice with ten questions, reading tests, and interviews. The data collected from the students' scores. The result showed that there is 0 student or $0 \%$ who was categorized excellent, there were two students or $6,67 \%$ who were classified as very good, there were seven students or $23,3 \%$ who categorized as good, there were seven students or $23,3 \%$ were categorized as fair, there were five students or $16,7 \%$ who were classified unsatisfactory. There were nine students or $30 \%$ who were categorized very poorly. So, from the result, the researcher can conclude that the students were still in the poor category.
\end{abstract}

Keywords: reading, comprehension; reading comprehension problem; descriptive

\title{
INTRODUCTION
}

Reading comprehension is one of language skill should mastered by students. Reading is a language skill learned in Senior High School. However, students must know and understand what they read. This condition decreased their reading ability and comprehension about what they read; it also affects the knowledge of students. The poor reader will start reading a passage much as you just did, without understanding the title and predicting what is in the text. Reading comprehension is a relational process between reader and book. 
Moat (2011), in reading, we must be able to understand the meaning of symbols and be able to create words. Difficulty in reading comprehension is no longer rarely heard because there have been many studies of the biggest problem in reading is to understand the contents of the text. However, reading does not only know about the book, but the students get information and add new vocabulary. Reading in a foreign language is a critical skill because it will increase his or her knowledge. There is some kind of text, such as descriptive text, narrative text, report text, procedure text, etc. Based on the researcher observation In SMA Pencawan Medan, the researcher found that the students had a low interest in reading English text. There hasn't been the definition, generic structure, even the kind of the book. They do not know the meaning of the text because of their lack of vocabulary, so that's making them not interested in learning English.

According to Anderson in Nunan (2003) that reading is a natural process of readers combining information from a text and their background knowledge to build meaning. These show that the information on the book is not enough to make a reader comprehend a text. To understand a version, a reader brought his previous knowledge on their topic and related it to the information in the book.

Reading comprehension is the process of simultaneously extracting and constructing meaning through interaction and involvement with written language (Snow, 2002) reading comprehension means how the reader can find out the message comprehend the text well. So, the teacher is not only to teach the students how to read, but how to understand and find out the meaning of the book. Based on the researcher's experience when they did a field teaching practice program, students are not interested in reading text. This situation happened because the teacher teaching with an old strategy, so they're lazy to study.

Woolley, (2011) state descriptive text is a text which says as what a person or the thing is like. Its purpose of describing the particular person, place, or words. The general structure of the descriptive text is Identification and Description-identification to explain the phenomenon. The description is described as parts, characteristics, and qualities. Descriptive writing is a kind of text with a purpose to give information. It explains how a thing is done (a place, a person, an animal). Students still have difficulties in reading descriptive text; the problems are the lack of vocabulary and lazy to reading book — the researcher focus on the descriptive text in this research. The researcher wants to find the difficulties of reading descriptive text.

This research had previously been conducted by Hariyadi et al. (2018) from the study conducted by researchers found 0 students or $0 \%$ in the excellent category, two students or $6,67 \%$ in the outstanding group, seven students or $23,3 \%$ in the as good grade, seven student or about $23,3 \%$ in the fair category, five student or approximately $16,7 \%$ as poor category and nine student or about 
$30 \%$ who was categorized very poor. Another research conducted by Siahaan (2013), the results found by researchers, some students have been able to write a semantic structure of descriptive text using appropriate linguistic features. But there are still confused students so that it is needed to improve their skills to write a descriptive paragraph.

In this study, the researcher analysis reading comprehension and difficulties in reading descriptive text. On the results of previous research was found that the students most problems in vocabulary. The students didn't know the meaning of the reading text, and also they lazy to bring a dictionary. The results were not explained to the students' difficulty in learning English. The researcher is interested to know students' comprehension and problems with reading descriptive text.

\section{LITERATUR REVIEW}

Understanding the Reading Text Oberholzer (2015) stated that "understanding the reading text is far more important than knowing the mechanical skill of reading. Without comprehension, reading would serve no purpose." It means that understanding the text is very important to the students because reading is not merely about mechanical skills. Therefore, understanding the book is not an easy thing, so that is why many students find difficulties in understanding the text.

Shalahuddin (1991) stated that "interest is a concern that contains elements of feeling. It can motivate the students to be active in their job or their activity." If the students' interest in reading, it will be easier for them to know what they read. Motivation is one of the essential things to support the students' read the book or text. As Brown points out, motivation includes factors such as the need for exploration, activity, stimulation, new knowledge, and ego enhancement. By giving motivation before the study can provide the students with such a new spirit to know about something by reading.

This research was also previously conducted by Salam (2018), who did her research in early junior high school with his research subjects in the eighth-grade academic year 2017/2018, where her research results showed that students' reading comprehension was still at an average level. The results show that in the identification section, students get an average value of 55, 75. In terms of describing 50.25 of the overall results, then after averaging, students get a value of 51. Hence, researchers assume that the ability to write descriptive text students are still limited to average.

Other research was also conducted by Dian (2019) at Mandau Junior High School in the academic year 2019/2020 to know students comprehending in reading descriptive text; she found that students' percentage of students' 
difficulties in learning a graphic book in terms of the level of the document (reliability) was $75.14 \%$.

\section{RESEARCH METHOD}

In this research, the researcher uses qualitative analysis. Qualitative is to find the result and collected the data from the object of the study. In this study, the writer used descriptive qualitative research method to expose the result. Place and purpose of the education the objective of this study was students' $11^{\text {th }}$ grade of SMA Swasta Pencawan Medan in the academic year 2019/2020. The Researcher conducted in class XI MIA -1 that consisted of 30 students. The instrument of collecting data in collecting data the writer used reading test with giving the form of a question of five descriptive texts.

The researcher interview to ask students' difficulties in answering the test paper and reading test used by the writer to analyzed reading comprehension in reading. After giving a trial, the writer collects the data from the worksheet of students and then identification the paper answer and gives it score. The researcher interviewed the students who have difficulties in comprehending the descriptive text. The students answered the question with their own words, and there was no alternative answer from the researcher.

The instruments used to support the research by collecting the data from teachers and students. The test will be an instruction to prepare some research procedures, as follow: 1) explained the material, 2) gave the reading test to the students, 3) collected the answer sheet, 4) conducts an interview.

After conducting reading tests, the researcher analyzed the score of the reading test. The researcher then calculated the score of a reading test and changed into the percentage of students' scores. After giving the reading test, the writer interviewed the students. The results of the interviewed were analyzed to find students' problems in understanding English texts. To get the score of students,' the writer used Arikunto's formula. The researcher calculated the students' reading test by using this formula:

$$
S=\frac{R}{T} \times 100
$$

Notes:

$\mathrm{S}=$ Score of the data analysis

$\mathrm{R}=$ Number of the correct answer

$\mathrm{T} \quad=$ Total of item 
In this step, the writer describes the students' score into some categorized Brown Theory states that to grading system can be classified into five categories, namely: excellent, very good, good, fair, weak, and very poor.

\begin{tabular}{cc}
\hline Score & Grade \\
\hline $90-100$ & Excellent \\
\hline $80-89$ & Very Good \\
\hline $70-79$ & Good \\
\hline $60-69$ & Fair \\
\hline $50-59$ & Poor \\
\hline Less than 50 & Very Poor \\
\hline
\end{tabular}

According to Best states that to calculating the test, it must be determined the value of the mean first. The calculating of the meaningful use of the formula below:

$$
\mathbf{M}=\frac{\sum x}{N}
$$

Where:

$$
\begin{array}{ll}
\mathrm{M} & =\text { Mean } \\
\sum x & =\text { Total Score } \\
\mathrm{N} & =\text { Number of Students }
\end{array}
$$

\section{FINDINGS}

The number of items test was ten items with multiple choice. When all scores were found, the writer gets only two students who got to score 80 , which is the highest score. After finding out the data, the researcher combined with the KKM of the subject, which has a category of how the students to understand the text. The KKM of SMA SwastaPencawan Medan is 75. From the result, the researcher concludes how the students to answer the book.

The data were shown below:

Table 1. The Students' Score on Reading Test

\begin{tabular}{ccc}
\hline No & Students' Initial Name & Score \\
\hline 1. & AM & 20 \\
\hline 2. & AS & 70 \\
\hline 3. & CS & 60 \\
\hline 4. & CB & 70 \\
\hline
\end{tabular}




\begin{tabular}{lcc}
\hline 5. & DAS & 40 \\
\hline 6. & EM & 50 \\
\hline 7. & EI & 60 \\
\hline 8. & FA & 50 \\
\hline 9. & FF & 60 \\
\hline 10. & HF & 30 \\
\hline 11. & IT & 50 \\
\hline 12. & LB & 60 \\
\hline 13. & LS & 70 \\
\hline 14. & NSS & 20 \\
\hline 15. & PS & 70 \\
\hline 16. & RE & 10 \\
\hline 17. & RL & 80 \\
\hline 18. & RAT & 70 \\
\hline 19. & RS & 60 \\
\hline 20. & RAR & 60 \\
\hline 21. & SVA & 40 \\
\hline 22. & SS & 50 \\
\hline 23. & SC & 70 \\
\hline 24. & TGS & 70 \\
\hline 25. & TAS & 60 \\
\hline 26. & TD & 30 \\
\hline 27. & TS & 50 \\
\hline 28. & UM & 40 \\
\hline 29. & YF & 80 \\
\hline 30. & YPA & 40 \\
\hline & TOTAL & $\mathbf{5 3 0}$ \\
\hline & MEAN & \\
\hline & & \\
\hline & &
\end{tabular}

Table 2. Students' Criteria

\begin{tabular}{cccc}
\hline No & Students' Initial Name & Score & Criteria \\
\hline 1. & AM & 20 & Very Poor \\
\hline 2. & AS & 70 & Good \\
\hline 3. & CS & 60 & Fair \\
\hline 4. & CB & 70 & Good \\
\hline 5. & DAS & 40 & Very Poor \\
\hline 6. & EM & 50 & Poor \\
\hline 7. & EI & 60 & Fair \\
\hline 8. & FA & 50 & Poor \\
\hline 9. & FF & 60 & Fair \\
\hline 10. & HF & 30 & Very Poor \\
\hline 11. & IT & 50 & Poor \\
\hline 12. & LB & 60 & Fair \\
\hline 13. & LS & 70 & Good \\
\hline
\end{tabular}




\begin{tabular}{lccc}
\hline 14. & NSS & 20 & Very Poor \\
\hline 15. & PS & 70 & Good \\
\hline 16. & RE & 10 & Very Poor \\
\hline 17. & RL & 80 & Very Good \\
\hline 18. & RAT & 70 & Good \\
\hline 19. & RS & 60 & Fair \\
\hline 20. & RAR & 60 & Fair \\
\hline 21. & SVA & 40 & Very Poor \\
\hline 22. & SS & 50 & Poor \\
\hline 23. & SC & 70 & Good \\
\hline 24. & TGS & 70 & Good \\
\hline 25. & TAS & 60 & Fair \\
\hline 26. & TD & 30 & Very Poor \\
\hline 27. & TS & 50 & Poor \\
\hline 28. & UM & 40 & Very Poor \\
\hline 29. & YF & 80 & Very Good \\
\hline 30. & YPA & 40 & Very Poor \\
\hline
\end{tabular}

\section{DISCUSSION}

This section presents the analysis based on the findings of the study. It concerned about students' difficulties and the factors causing the problems in understanding English reading descriptive text. The researcher identifies by analyzed worksheets and students' answers. It is in line with Kennedy ${ }^{\text {ee }}$ s theory (1981). It is difficult to any, but the most thoroughly disciplines readers to concentrate on material 75 they dislike or that related to their interest. In his research, Mahmud (2014) said that the most significant difficulty of high students in answering questions because top students do not have the skills and motivation to read. The researcher categorized the student"s score into four categories using Brown theory (2003) there is excellent, very good, good, fair, weak, and very poor.

Researchers provided the database on the result of students' scores, from the result show that there was 0 student or $0 \%$ who was categorized excellent. There were seven students or $23,3 \%$ who were classified as useful. There were seven students or $23,3 \%$ who were categorized as fair. There were five students or $16,7 \%$ who were categorized as weak. There were students 9 or $30 \%$ who were classified as very poor. Freeman and Long stated that a teacher is a subject in education who must transfer the knowledge to the students. Most of the students' said their teacher's technique is not unusual, she does not give explicit instruction in teaching reading; he rarely uses media in teaching and cannot create exciting activity in learning. A similar opinion was also expressed by Syakira (2016), who said that students are reading on the descriptive text in the average category. 
In his research, he found students still had many difficulties in reading explanatory books.

Based on the data, the researchers found that some factors that make students' comprehension and difficulties in reading descriptive text are: The first factor of students' problems on reading a graphic book in eleventh-grade students' was the low vocabulary mastery. It happened to many students of XI MIA -2 in the academic year 2019/2020. The students did not understand the English text that the researcher gave. The students' lazy to bring a dictionary; they preferred to ask the teacher the meaning of the problematic word.

Also, thinking critically is the ability to reason in an organized way. This is an essential mental activity in comprehending a reading text because reading comprehension is an active process between the reader and the book. In the process, the reader needs to bring what he/she knows about the topic and related it to the information on the text. Thinking critically make the students use their knowledge and intelligence effectively (Caroll, 2004).

The second factor is that the students' that still use the textbook on their teaching-learning process. They did not have other books as references. The facilities such as in focus and speaker not available make them bored. Having a reason to learn, of course, make the students are interested to learn. The teacher sometimes is monotonous, so that makes the students not interested in studying English.

\section{CONCLUSION}

In this part the writer drew the following conclusion: The students of SMA Swasta Pencawan Medan, the result showed that there are three problems the students face in understanding English reading descriptive text that is 1) lack of students, interest 2) lazy to study English 3) lack of vocabulary mastery.

\section{REFERENCES}

Brown, H., D. (2003). Reading on Second Language Acquisition. New York: Longman.

Carroll, R., T. (2004). Critical thinking. Retrieved in 2012, March, from http://www.scribd.com/doc/16426858/Critical-Thinking-Ch1-Drrobert Todd-Carroll.

Dian H.,N, (2019) An Analysis of Students' Difficulties in Comprehending Narrative Text at Senior High School 8 Mandau. Skripsi thesis, Universitas Islam Negeri Sultan Syarif Kasim Riau.

Haryadi, P., \& Wennyta, N., F. (2018). An Analysis of Students' Ability In Writing Descriptive Text at The Tenth Grade Students of SMAN 11 Jambi Academic Year.Jelt: Journal of English Language teaching, 2(2) 
Kennedy, E,. C. (1981). The Method of Teaching Development Reading. Washington: Peacock Publisher.

Moats, L., C. (2001). Teaching reading is rocket science: What expert teachers of reading should know and be able to do. Washington, DC: American Federation of Teachers.

Mahmud, M. (2014). The EFL students' problems in answering the test of English as a Foreign Language (TOEFL): A study in the Indonesian context. Theory and Practice in Language Studies, 4(12): 2581 -258

Nunan, D. (2003). Practical English Language Teaching.New York: McGraw Hill Companies, Inc.

Oberholzer, B. (2005). The Relationship Between Reading Difficulties and Academic Performance (Submitted in part fulfiIment of the requirements for the degree of M Ed (Ed. Psych) in the Department of Educational Psychology at the University of Zululand, 2005).

Salam, R., S., 2018. Analysis of Students' Reading Comprehension of Descriptive Text at Seventh Grade at SMP Pangeran Antasari Medan. STKIP Riama Medan.

Shalahuddin. (1991). Students motivation learning. Washington DC : American federation

Siahaan, J. (2013). An Analysis of Students' Ability and Difficulties in Writing Descriptive Texts. Bandung: Alphabeta

Snow. (2010). Reading Comprehension For Learning In Harvard Graduate School of Education, Cambridge Journal (5) 5.

Syakira, A (2016). Analysis of the Students' Reading Comprehension in Comprehending Descriptive Text. In Journal Surakarta Kartawijaya Sekolah Tinggi Sakti Alam Kerinci.

Woolley, G. (2011). Teaching English. In Australian Journal of Language and Literacy, 33 (2), 108-125. 